\title{
Analysis of the control structures for an integrated ethanol processor for proton exchange membrane fuel cell systems
}

\author{
S. Biset ${ }^{\mathrm{a}}$, L. Nieto Deglioumini ${ }^{\mathrm{a}}$, M. Basualdo ${ }^{\mathrm{a}, *}$, V.M. Garcia $^{\mathrm{b}}$, M. Serra ${ }^{\mathrm{b}}$ \\ a GIAIP-CIFASIS (UTN-FRRo-CONICET-UPCAM-UNR), BV. 27 de Febrero 210 Bis, S2000EZP Rosario, Argentina \\ ${ }^{\mathrm{b}}$ Institut de Robòtica i Informàtica Industrial, C. Llorens i Artigas 4-6, 08028 Barcelona, Spain
}

\section{A R T I C L E I N F O}

\section{Article history:}

Received 14 October 2008

Received in revised form 16 December 2008

Accepted 19 December 2008

Available online 30 December 2008

\section{Keywords:}

Fuel cells

Bioethanol reforming

Hydrogen production

Plant wide control

\begin{abstract}
A B S T R A C T
The aim of this work is to investigate which would be a good preliminary plantwide control structure for the process of Hydrogen production from bioethanol to be used in a proton exchange membrane (PEM) accounting only steady-state information. The objective is to keep the process under optimal operation point, that is doing energy integration to achieve the maximum efficiency. Ethanol, produced from renewable feedstocks, feeds a fuel processor investigated for steam reforming, followed by high- and lowtemperature shift reactors and preferential oxidation, which are coupled to a polymeric fuel cell. Applying steady-state simulation techniques and using thermodynamic models the performance of the complete system with two different control structures have been evaluated for the most typical perturbations. A sensitivity analysis for the key process variables together with the rigorous operability requirements for the fuel cell are taking into account for defining acceptable plantwide control structure. This is the first work showing an alternative control structure applied to this kind of process.
\end{abstract}

\section{Introduction}

The current industrial hydrogen production technology could only partially meet the requirement of the small-scale fuel processors, which must be compact, turnkey and of high efficiency by combining component functionalities and eliminating unnecessary components. Although the on-board fuel processor program has been put on hold by the U.S. Department of Energy (DOE), a number of new approaches for the establishment of hydrogen refueling station based on some form of a fuel processor are being pursued [1]. Particularly among all the alcohols, methanol is the most popular fuel for reforming, not only because it requires mild reforming conditions and has potential for attainment of highest possible efficiency, but also because of its possibility to be produced from renewable resources [2,3]. Another alcohol is ethanol, which is already used as one of the main additives for gasoline for both its high octane number (RON and MON) and low toxicity, has gained popularity for its environmentally friendliness as well as sustainability [4]. Biomass, including bioethanol and other high molecular weight materials such as sugar alcohol is considered to be promising raw material in terms of their carbon cycling neutrality. Conventionally, hydrogen can be obtained by high temperature gasification/pyrolysis of biomass followed by catalytic reforming of the gas/liquid product [5]. A good recent review about different

\footnotetext{
* Corresponding author. Tel.: +54 341482 1771/6300x104; fax: +54 3414821772. E-mail address: basualdo@cifasis-conicet.gov.ar (M. Basualdo).
}

technologies for integrated fuel processors for fuel cell application is given in Qi et al. [6]. They emphasized that process intensification technologies such as engineered catalysts, on-site heat production/removal and product purification can not only allow precise control of reaction and heat/mass transfer rates, but also help optimize the operation conditions, and, consequently, improve overall efficiency and mitigate the requirement for materials and capital investment.

On the other side, feedback control of fuel cell power systems has recently started to attract attention. Several control problems for fuel cell-powered electric vehicles are outlined in Powers and Nicastri [7]. Boettner et al. [8] have identified control opportunities for the compressor within the fuel cell system. Control of the electrical power output and oxidant supply in electrical power generation for a fuel cell powered vehicle is discussed in Mufford and Strasky [9]. Pukrushpan et al. [10] have derived a lumped dynamic model of the cell stack, and regulated the net power output by controlling the air supply to the cathode. More recently, a comparison of PI and LQG controls for air supply is presented in Rodatz et al. [11]. In Pukrushpan et al. [12] have demonstrated a model-based multivariable control design for the fuel processing system (FPS) to regulate the temperature of $\mathrm{CPO}$ and the mole fraction of hydrogen in the anode. Gorgun [13] presented a control-oriented physicsbased modeling of FPS reactors in fuel cell power systems. In both last references methane is used as the feed and dynamic models were employed for defining the proposed control structure.

As the authors understand, up to now, there is no works considering the overall FPS with PEM, using bioethanol, where the 


\begin{tabular}{|c|c|}
\hline \multicolumn{2}{|c|}{ Nomenclature } \\
\hline$E_{\mathrm{rev}}$ & reversible open circuit voltage \\
\hline$f$ & molar flow rate \\
\hline$F$ & Faraday constant \\
\hline FA & water flow to the reformer \\
\hline FE & ethanol flow to the reformer \\
\hline FEC & ethanol flow to the burner \\
\hline$h$ & specific heat \\
\hline$i_{\text {Cell }}$ & load current cell \\
\hline$P_{\text {Cell }}$ & actual electrical power generated \\
\hline$P_{\text {system }}$ & net power produced by the fuel cell system \\
\hline$Q_{\text {PEM }}$ & heat produced by the cell \\
\hline$R$ & water/ethanol molar ratio \\
\hline$R_{\mathrm{g}}$ & universal gas constant \\
\hline$T_{\# 23}^{\circ}$ & temperature of stream \#23 \\
\hline$U$ & manipulated variables \\
\hline$V_{\text {Cell }}$ & actual cell voltage \\
\hline$W$ & perturbations \\
\hline$W_{\text {comp }}$ & work of the compressor \\
\hline $\mathrm{XE}$ & ethanol molar fraction \\
\hline Y & controlled process variables \\
\hline$Z$ & performance variables \\
\hline \multicolumn{2}{|c|}{ Acronyms } \\
\hline DMC & dynamic matrix control \\
\hline ESR & ethanol steam reforming \\
\hline FPS & fuel processor system \\
\hline HHV & higher heating value \\
\hline HTS & high temperature water gas shift \\
\hline LHV & lower heating value \\
\hline LTS & low temperature water gas shift \\
\hline \multicolumn{2}{|c|}{ PEM-FCS proton exchange membrane-fuel cell stack } \\
\hline PrOx & preferential oxidation \\
\hline WGS & water gas shift \\
\hline \multicolumn{2}{|c|}{ Greek letters } \\
\hline$\eta$ & efficiency \\
\hline$\varphi$ & drop potential due to the operation irreversibility \\
\hline \multicolumn{2}{|c|}{ Subscripts } \\
\hline $\mathrm{a}$ & anode \\
\hline Burn & burner, post-combustion reactor \\
\hline c & cathode \\
\hline Cell & fuel cell stack \\
\hline Et & ethanol \\
\hline Ref & reformer reactor \\
\hline Rev & reversible \\
\hline \multicolumn{2}{|c|}{ Superscripts } \\
\hline in & inlet condition \\
\hline out & outlet condition \\
\hline
\end{tabular}

main control structure is analyzed through a steady-state model. It is remarked because generally the steady-state model is the only available information for doing preliminary tests. Hence, in this work, a control-oriented steady-state model of an ethanol processor for hydrogen production and fuel cell operation is developed. The rigorous model consists of mass and energy balances, chemical equilibrium and feasible heat transfer conditions elements. The FPS converts a bioethanol fuel to a hydrogen $\left(\mathrm{H}_{2}\right)$ rich mixture that is directly fed to the proton exchange membrane fuel cell (PEM-FC). Since ethanol can be produced from renewable feedstocks or agriculture residues, is an attractive option as a fuel source. The overall plant studied here includes an ethanol steam reforming (ESR), water gas shift (WGS) and preferential oxidation (PrOx) reactors for the fuel processing, followed by a PEM-FC and a post-combustion unit. The conceptual design of this plant was presented by Francesconi et al. [14] in order to achieve a highly heat integrated system. The study presented there, about cost and performance requirements of the total power plant, was extremely useful in understanding the system level interactions, implications on system performance and for control structure synthesis since the conceptual design stage. Therefore, a proper plantwide control structure design is proposed to keep the optimal operation point.

In this paper, some control theoretic tools such as sensitivity analysis to critical perturbations, as given by Luyben and Luyben [15] and Luyben et al. [16], as well as some assumptions suggested in Pukrushpan et al. [12] are accounted. Even though in this last work the feed to the FPS is methane and did not consider any heat integration system some analogous aspects were helpful as a guide to understand better both steady-state and dynamic behavior. In this context, the problem is how to handle the integrated system efficiency accounting the best operating conditions of the reformer, the effect of the inlet temperature to the WGS and PrOx reactors, combustion preheating, expander unit, crude ethanol as fuel and the PEM specifications.

The main operating variables were determined by Francesconi et al. [14] considering that the endothermic nature of the reformer has a significant effect on the overall system efficiency. The highest energy consumption is demanded by the reforming reactor, the evaporator and re-heater operations. To obtain an efficient integration, the heat exchanged between the reformer outgoing streams of higher thermal level (reforming and combustion gases) and the feed stream should be maximized. Another process variable that affects the process efficiency is the water-to-fuel ratio fed to the reformer. Large amounts of water involve large heat exchangers and the associated heat losses. A net electric efficiency around 32\% was calculated based on the ethanol higher heating value (HHV). The responsibilities for the remaining $68 \%$ are: dissipation as heat in the PEM-FC cooling system (38\%), energy in the fuel gases (10\%) and irreversibility in compression and expansion of gases (20\%).

In this work, a commercial simulator was used to solve the mass and energy balances, and to compute the operating conditions for the process units under the most critical disturbances. The process under study was implemented within HYSYS ${ }^{\circledR}$ flow sheeting software [17]. Maximum heat integration within the system is necessary to achieve acceptable net electrical efficiency levels. The use of process integration techniques applying pinch analysis has already been reported for the design of a heat exchange network for integrated PEM fuel cell systems [18]. In this paper, the heat exchanger network involving the reformer, burner, gas cleaning units and the PEM-FC stack was modeled using the LNG exchanger model which is a tool available in HYSYS ${ }^{\circledR}$. This allows identifying the most successful heat exchange opportunities, and to define the optimal operating conditions of the ethanol processor for obtaining the best global efficiency considering the plant balances. The analysis considered here would be useful as a basis for further process dynamic simulation working at the optimal structure determination and testing whether or not the proposed control structure works well for each time instant.

\section{Description of the fuel processor system}

The fuel processing plant has been built according to Francesconi et al. [14] recommendations. The fuel processor chemically converts ethanol to hydrogen including a hydrogen cleanup equipment, the fuel cell stack electrochemically converts the hydrogen energy to electric power. Additionally, associated equipment for heat, air and water management, and auxiliary equipment such as pumps and 


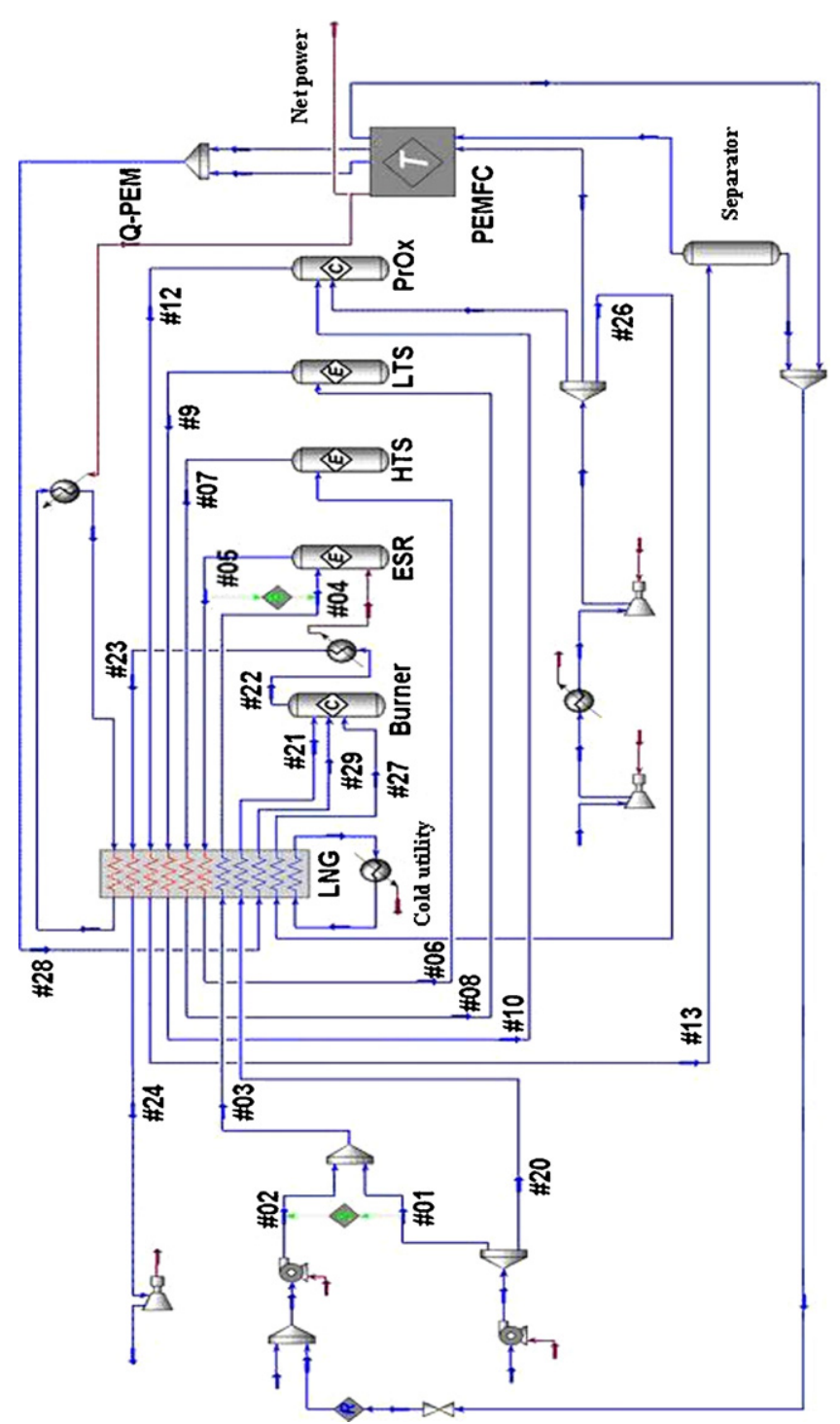

Fig. 1. Plant of the fuel processor system with PEM model in HYSYS ${ }^{\circledR}$.

blowers are accounted. Fig. 1 shows the main components: ethanol steam reformer (ESR), high (HTS) and low (LTS) temperature water gas shift reactors, a preferential oxidation reactor of $\mathrm{CO}$ (PrOx), a PEM-FC, a combustor, compressors and an expander. For the steadystate model the pressure drops are neglected and the operating pressure is fixed at $3 \mathrm{~atm}$. The inlet flows depicted in Fig. 1 are the following: Stream \#01 is the ethanol flow provided at $25^{\circ} \mathrm{C}$. Stream \#02 is the water flow required for the steam reformer whose flow
Table 2

Fuel processor streams connected to the LNG unit.

\begin{tabular}{lcccc}
\hline Pass & & Input $\left({ }^{\circ} \mathrm{C}\right)$ & Output $\left({ }^{\circ} \mathrm{C}\right)$ & $Q(\mathrm{~kW})$ \\
\hline \#03-\#04 (vaporizing) & Cold & 61.32 & 126 & 0.45 \\
\#03-\#04 (reheater) & Cold & 127 & 709 & 0.32 \\
\#28-\#29 & Cold & 80 & 500 & 0.67 \\
\#20-\#21 & Cold & 25 & 300 & 0.09 \\
\#26-\#27 & Cold & 127.2 & 300 & 0.00 \\
Cold utility & Cold & 20 & 25 & 2.36 \\
ESR duty & Cold & 709 & 709 & 0.41 \\
\#05-\#06 & Hot & 709 & 500 & 0.13 \\
\#07-\#08 & Hot & 538.9 & 150 & 0.23 \\
\#12-\#13 & Hot & 406 & 80 & 0.23 \\
\#23-\#24 & Hot & 850 & 287 & 0.95 \\
\#22-\#23 & Hot & 1072 & 850 & 0.41 \\
Q-PEM & Hot & 65 & 55 & 2.27
\end{tabular}

rate is controlled by the water to ethanol molar ratio. Stream \#30 is the airflow required for the operation of combustor, fuel cell and the PrOx units. In the integrated system, the air compressor will be driven by a turbine expanding the post combustion gases. The compressor, expander and pumps isentropic efficiencies are $75 \%$. The inlet air conditions are $1 \mathrm{~atm}, 25^{\circ} \mathrm{C}$. The most important operating conditions are summarized in Tables 1 and 2.

The ideal unit cell voltage is calculated through (1), adopted from Godat and Marechal [19]:

$E_{\mathrm{rev}}=E_{\mathrm{rev}}^{0}\left(T_{\text {Cell }}\right)+\frac{R_{\mathrm{g}} \cdot T_{\text {Cell }}}{2 F} \cdot\left[\ln \left(p_{\mathrm{H}_{2}, \mathrm{a}}^{*}\right)+\frac{1}{2} \ln \left(p_{\mathrm{O}_{2}, \mathrm{c}}^{*}\right)\right]$

where $E_{\mathrm{rev}}$ is the voltage calculated for the cell temperature $\left(T_{\text {Cell }}\right)$, and $p_{\mathrm{H}_{2}, \mathrm{a}}^{*}$ and $p_{\mathrm{O}_{2}, \mathrm{c}}^{*}$ are the partial pressure for $\mathrm{H}_{2}$ and $\mathrm{O}_{2}$ averaged (arithmetic mean) between the inlet and outlet conditions.

Useful work (electrical energy) is obtained from a fuel cell only when a current is drawn, but the actual cell voltage $\left(V_{\text {Cell }}\right)$ is decreased from its equilibrium thermodynamic potential $\left(E_{\mathrm{rev}}\right)$ because of irreversible losses. When current flows, a deviation from the thermodynamic potential occurs corresponding to the electrical work performed by the cell. Therefore, the expression of the voltage of a single cell is

$V_{\text {Cell }}=E_{\mathrm{rev}}-\varphi$,

where $\varphi$ is the drop potential due to the operation irreversibility which represents the deviation from the equilibrium value. The actual electrical power generated by the cell $\left(P_{\text {Cell }}\right)$ can then be calculated from

$P_{\text {Cell }}=V_{\text {Cell }} \times i_{\text {Cell }}$.

The operating voltage is defined as the power level at which unit cell voltage drops to $0.5 \mathrm{~V}$ from the ideal voltage [5]. The current $i_{\text {Cell }}$ is related with the hydrogen molar flow rate at the anode.

$i_{\text {Cell }}=2 F \cdot\left(f_{\mathrm{H}_{2}, \mathrm{a}}^{\text {in }}-f_{\mathrm{H}_{2}, \mathrm{a}}^{\text {out }}\right)$

Table 1

Heating and cooling demands for the system streams.

\begin{tabular}{|c|c|c|c|c|c|c|c|}
\hline Stream number & \#04 & \#05 & \#07 & $\# 09$ & \#12 & \#14 & \#28 \\
\hline Temperature $\left({ }^{\circ} \mathrm{C}\right)$ & 709 & 709 & 538.9 & 236.7 & 406 & 80 & 80 \\
\hline Pressure (atm) & 3 & 3 & 3 & 3 & 3 & 3 & 3 \\
\hline Mole flow $\left(\mathrm{kmol} \mathrm{h}^{-1}\right)$ & 0.03670 & 0.06284 & 0.06284 & 0.06284 & 0.06284 & 0.06360 & 0.17497 \\
\hline \multicolumn{8}{|l|}{ Molar fraction } \\
\hline Hydrogen & 0.8000 & 0.48602 & 0.52206 & 0.59209 & 0.54734 & 0.56642 & 0.04117 \\
\hline $\mathrm{H}_{2} \mathrm{O}$ & 0.0000 & 0.28037 & 0.24433 & 0.17430 & 0.18431 & 0.15588 & 0.15589 \\
\hline Methane & 0.0000 & 0.02561 & 0.02561 & 0.02561 & 0.02445 & 0.02523 & 0.00919 \\
\hline $\mathrm{CO}$ & 0.0000 & 0.11235 & 0.07631 & 0.06278 & 0.00002 & 0.00002 & 0.00001 \\
\hline $\mathrm{CO}_{2}$ & 0.0000 & 0.09566 & 0.13169 & 0.20173 & 0.19856 & 0.20547 & 0.07467 \\
\hline Ethanol & 0.2000 & 0.00000 & 0.00000 & 0.00000 & 0.00000 & 0.00000 & 0.00000 \\
\hline Oxygen & 0.0000 & 0.00000 & 0.00000 & 0.00000 & 0.00008 & 0.00008 & 0.08233 \\
\hline Nitrogen & 0.0000 & 0.00000 & 0.00000 & 0.00000 & 0.04525 & 0.04682 & 0.63667 \\
\hline
\end{tabular}


Table 3

Optimal values for the key system variables.

\begin{tabular}{lll}
\hline & Description & Optimal value \\
\hline$T_{\text {Ref }}$ & Temperature reactor ESR & $709^{\circ} \mathrm{C}$ \\
$T_{\mathrm{HTS}}$ & Temperature reactor HTS & $500^{\circ} \mathrm{C}$ \\
$T_{\mathrm{LTS}}$ & Temperature reactor LTS & $150^{\circ} \mathrm{C}$ \\
$T_{\mathrm{PrOx}}$ & Temperature reactor PrOx & $237^{\circ} \mathrm{C}$ \\
$R$ & Molar ratio $\mathrm{H}_{2} \mathrm{O}-\mathrm{ethanol}$ & 4 \\
$\mathrm{O}_{2} / \mathrm{CO}$ & Feed relationship $\mathrm{O}_{2}-\mathrm{CO}$ for & 2 \\
& the PrOx & \\
$\mathrm{O}_{2} / \mathrm{H}_{2}$ & Flor relationship $\mathrm{O}_{2}-\mathrm{H}_{2}$ at & 4.76 \\
& the PEM & \\
$P_{\text {Cell }}$ & Power cell & $0.8027 \mathrm{~kW}$ \\
$X_{\mathrm{CO}}$ & Molar Fraction de CO & $10 \mathrm{ppm}$ \\
$P_{\text {ESR }}$ & Pressure at ESR & $304 \mathrm{kPa}$ \\
$P_{\mathrm{HTS}}$ & Pressure at HTS & $304 \mathrm{kPa}$ \\
$P_{\text {LTS }}$ & Pressure at LTS & $304 \mathrm{kPa}$ \\
$P_{\text {PrOx }}$ & Pressure at PrOx & $304 \mathrm{kPa}$ \\
$P_{\text {Burner }}$ & Pressure at the burner & $304 \mathrm{kPa}$ \\
$T_{\text {Cell }}$ & Cell temperature & $80{ }^{\circ} \mathrm{C}$ \\
$P_{\text {\#Cathode exhausted }}-P_{\text {\#Anode exhausted }}$ & Pressure difference at PEM & $\mathrm{Min}$ \\
$H_{\text {Mem }}$ & Membrane humidity at & $80 \%$ \\
& PEM & \\
\hline
\end{tabular}

By doing an energy balance over the cell from the inlet to the outlet conditions, the heat produced by the cell which has to be removed is given by

$Q_{\text {PEM }}=\sum_{i=1}^{\text {inlets }} f_{i} h_{i}\left(T_{\text {Cell }}\right)-\sum_{o=1}^{\text {outlets }} f_{o} h_{o}\left(T_{\text {Cell }}\right)-P_{\text {Cell }}$

It is assumed isothermal and isobar PEM.

\subsection{Main process variables to be accounted}

From the work of Francesconi et al. [14] can be extracted which are the main process variables and their optimal values since the minimun energy consumption point of view at the conceptual design stage. This information is listed here in Table 3.

\section{Control problem formulation}

As previously discussed, one of the key requirements of the FPS controller is to quickly replenish the hydrogen that is consumed in the fuel cell anode during current (load) changes. On the other hand, the FPS controller needs to reduce the $\mathrm{H}_{2}$ generation when there is a step-down in the current drawn from the fuel cell, so $\mathrm{H}_{2}$ do not to be wasted. This $\mathrm{H}_{2}$ on demand operation involves the following objectives (i) to protect the stack from damage due to $\mathrm{H}_{2}$ starvation, (ii) to protect ESR from overheating and (iii) to keep overall system efficiency high, which includes high stack $\mathrm{H}_{2}$ utilization and high FPS ethanol-to- $\mathrm{H}_{2}$ conversion. Objectives (i) and (ii) are important during transient operations while objective (iii) can be viewed as a steady-state goal. Objectives (ii) and (iii) are also related since keeping the desired ESR temperature during steady-state implies proper regulation of the oxygen-to-carbon ratio which corresponds to high FPS conversion efficiency.

The stack current, $I_{\text {load }}$, is considered as an exogenous input that is measured. The control problem is formulated using the general control configuration shown in Fig. 2.

The PEM control is formulated based on Feroldi et al. [20] considerations based on the advantages of using a regulating valve for the cathode outlet flow in combination with the compressor motor voltage as manipulated variables in a fuel cell system. At a given load current, the cathode input and output flow rate determine the cathode pressure and stoichiometry, and consequently determine the oxygen partial pressure, the generated voltage and the compressor power consumption. Therefore, in order to maintain a high

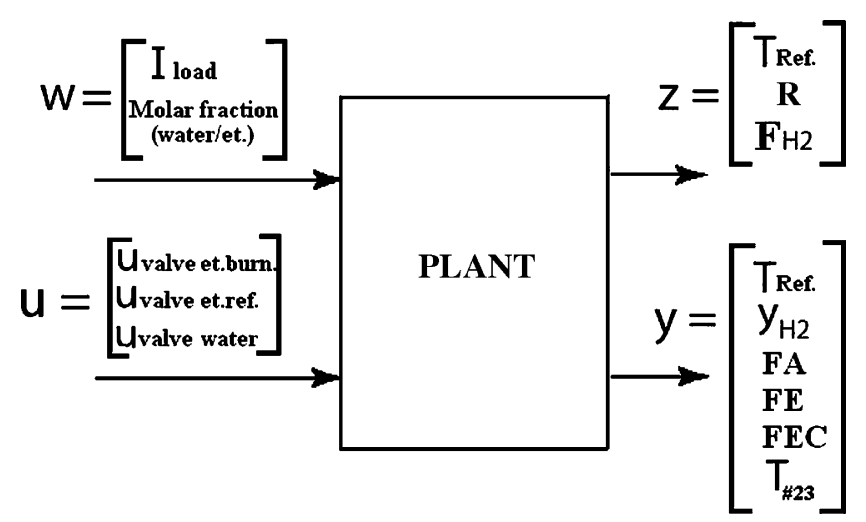

Fig. 2. Generalized block diagram for the plant control structure.

efficiency during operation, the cathode output regulating valve has to be adjusted to the operating conditions, specially marked by the current drawn from the stack. In addition, in [6] is demonstrated that the appropriate valve manipulation produces an improvement in the system transient response. The implementation was done with a predictive control strategy based on dynamic matrix control (DMC), using the compressor voltage and the cathode output regulating valve as manipulated variables. Hence, both the fuel cell voltage and oxygen excess ratio in the cathode, are regulated and thus, the system performance can be improved.

\subsection{Assumptions for control problem simplification}

Several assumptions are made in order to simplify the control of the FPS. Since the control of the three cleaning reactors (two water gas shift, WGS, of high and low temperature and the preferential oxidation, PrOx) are not studied, the three components are lumped together as one volume. It is also assumed that all of them are perfectly controlled such that the desired values of the reactants are supplied to the reactors. It is assumed that the composition of the air entering to the blower is constant. Additionally, any temperature other than that of the ESR is assumed to be determined optimally by the LNG HYSYS tool which represents a perfectly controlled heat exchange network. Finally, all gases obey the ideal gas law and are perfect mixtures.

Based on all of these considerations, it is assumed as the most critical process variables to be controlled are the ESR temperature, the relationship of $\mathrm{H}_{2} \mathrm{O}$-ethanol at the feed plant and the feed flow rate of $\mathrm{H}_{2}$ to the PEM. In Fig. 2 can be seen the generalized block diagram representing the main plant control variables accounted:

$W$ (perturbations): feed molar fraction $\left(\mathrm{H}_{2} \mathrm{O}\right.$-ethanol), current demands and $\mathrm{H}_{2}$ feed flow rate;

$U$ (manipulated variables): the pre-heated ethanol flow rate valve, the ethanol feed flow rate to the burner and the water recycle feed flow rate from the PEM;

$Z$ (performance variables): $T_{\text {Ref }}, R$ and feed flow rate to the PEM; $Y$ : controlled process variables.

Therefore the control objectives are to keep the performance variables under optimal values, given by the synthesis stage, through variations on the manipulated variables even though perturbations occur.

\subsection{Proposed plant wide control structures}

Based on the previous study in the following sections two control structures are analyzed based on a sensitivity evaluation to the most critical perturbations. 


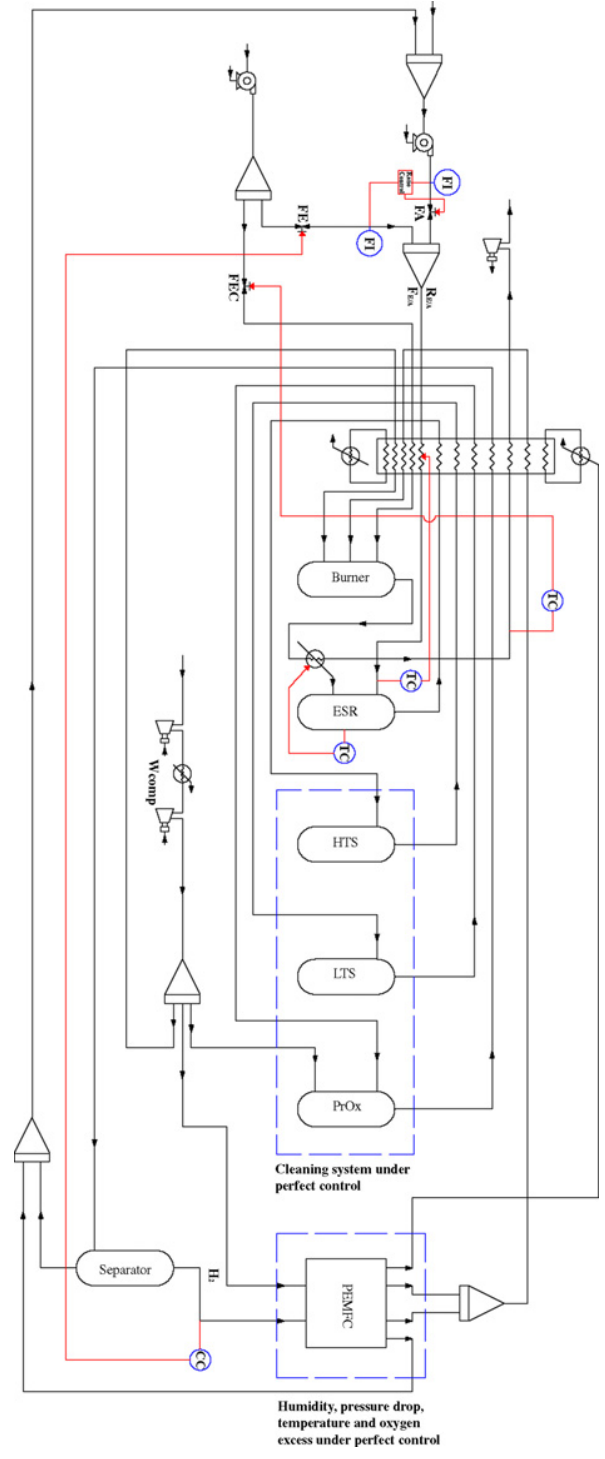

Fig. 3. Control Structure No. 1.

\subsubsection{Structure No. 1}

This structure can be seen in Fig. 3 which consists on controlling molar relationship between ethanol-water through a ratio control, the ESR temperature through the heat duty given from the exhausted gases of the burner. The ethanol feedflow rate to the ESR is manipulated according to the $\mathrm{H}_{2}$ requirements for the PEM.

\subsubsection{Structure No. 2}

This structure can be seen in Fig. 4 which consists on controlling molar relationship between ethanol-water through a ratio control, the ESR temperature through ethanol feed flow rate to the burner, and its temperature through the heat duty given by the exhausted gases to the ESR $\left(T_{\# 23}\right)$. The ethanol feedflow to the ESR is manipulated according to the $\mathrm{H}_{2}$ requirements for the PEM.

\section{Results}

A chemical plant typically has a large number of units with multiple recycle streams. Many different control strategies are possible, and it would be impractical to perform a detailed dynamic study for each alternative. An alternative procedure is to screen out poor control structures which can be done accounting with a steady-state process model trying to deal with problems such as snowball effect,

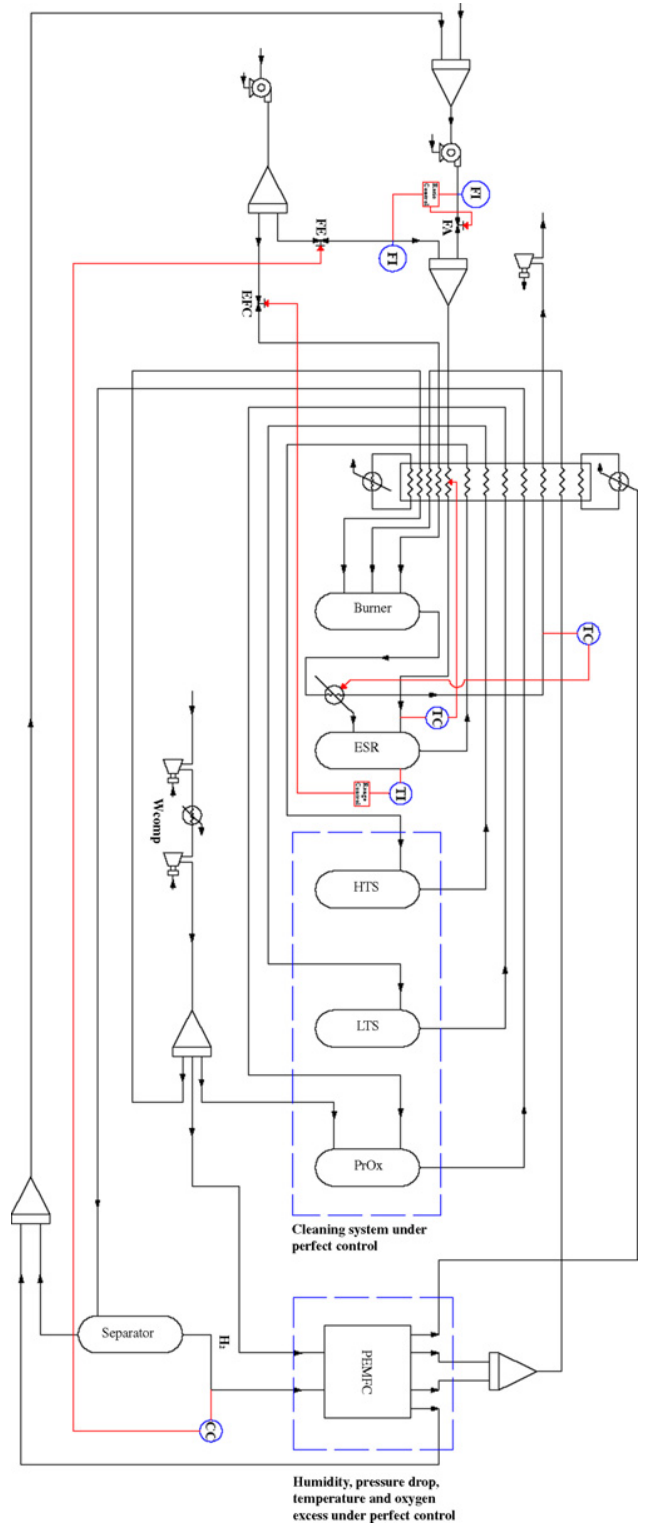

Fig. 4. Control Structure No. 2.

produced sometimes by material recycle. The principal objective is to use a steady-state analysis that can reveal structures that require large changes in manipulated variables when load disturbances occur or when a change throughput is made. These structures can be eliminated from further study. The idea is to specify a control structure (fix the variables that are held constant in the control scheme) and specify a disturbance. Then, solve the nonlinear algebraic equations to determine the values of all variables at the new steady-state condition. For realistically complex processes, analytical solution is out of the question and numerical methods must be used. The use of modern software tools (such as SPEEDUP, HYSYS ${ }^{\circledR}$, or GAMS) which make these calculations relatively easy to perform is recommended by Luyben [21]. Hence, in order to justify the control structures selection the FPS modeled in HYSYS ${ }^{\circledR}$ is tested.

Follow this methodology and assuming as critical disturbances the water molar fraction in the feed flow rate and the current load demand for both structures are analyzed. As can be seen from Tables 4-7 how these perturbation impact on the manipulated variables FA, FE and FEC and on the efficiency. Here the overall efficiency of the FCS is the same defined by Francesconi et al. [14] as the net energy output of the system obtained from the gross output by 
Table 4

Sensitivity analysis for control Structure No. 1.

\begin{tabular}{|c|c|c|c|c|c|c|c|}
\hline & Base case & $\mathrm{XE}(-1 \%)$ & Variation (\%) & $\mathrm{XE}(-5 \%)$ & Variation (\%) & $\mathrm{XE}(-10 \%)$ & Variation (\%) \\
\hline \multicolumn{8}{|l|}{ Disturbance in water molar fraction } \\
\hline XE (ethanol molar fraction in \%) & 1 & 0.99 & -1.000 & 0.95 & -5.000 & 0.9 & -10.000 \\
\hline $\mathrm{FA}\left(\mathrm{kmol} \mathrm{h}^{-1}\right)$ & $2.936 \mathrm{E}-02$ & $2.955 \mathrm{E}-02$ & 0.647 & $3.039 \mathrm{E}-02$ & 3.508 & $3.156 \mathrm{E}-02$ & 7.493 \\
\hline $\mathrm{FE}\left(\mathrm{kmol} \mathrm{h}^{-1}\right)$ & $7.340 \mathrm{E}-03$ & $7.388 \mathrm{E}-03$ & 0.654 & $7.597 \mathrm{E}-03$ & 3.501 & $7.890 \mathrm{E}-03$ & 7.493 \\
\hline $\mathrm{FEC}\left(\mathrm{kmol} \mathrm{h}^{-1}\right)$ & $7.581 \mathrm{E}-04$ & $7.878 \mathrm{E}-04$ & 3.918 & $9.159 \mathrm{E}-04$ & 20.815 & $1.086 \mathrm{E}-03$ & 43.253 \\
\hline Efficiency & 0.2881 & 0.2881 & 0.000 & 0.2880 & -0.035 & 0.2878 & -0.104 \\
\hline
\end{tabular}

Table 5

Sensitivity analysis for control Structure No. 2 .

\begin{tabular}{|c|c|c|c|c|c|c|c|}
\hline & Base case & $\mathrm{XE}(-1 \%)$ & Variation (\%) & $\mathrm{XE}(-5 \%)$ & Variation (\%) & $\mathrm{XE}(-10 \%)$ & Variation (\%) \\
\hline \multicolumn{8}{|l|}{ Disturbance in water molar fraction } \\
\hline XE (ethanol molar fraction in \%) & 1 & 0.99 & -1.000 & 0.95 & -5.000 & 0.9 & -10.000 \\
\hline $\mathrm{FA}\left(\mathrm{kmol} \mathrm{h}^{-1}\right)$ & $2.936 \mathrm{E}-02$ & $2.968 \mathrm{E}-02$ & 1.090 & $3.094 \mathrm{E}-02$ & 5.381 & $3.220 \mathrm{E}-02$ & 9.673 \\
\hline $\mathrm{FE}\left(\mathrm{kmol} \mathrm{h}^{-1}\right)$ & $7.340 \mathrm{E}-03$ & $7.420 \mathrm{E}-03$ & 1.090 & $7.734 \mathrm{E}-03$ & 5.368 & $8.049 \mathrm{E}-03$ & 9.659 \\
\hline $\mathrm{FEC}\left(\mathrm{kmol} \mathrm{h}^{-1}\right)$ & $7.566 \mathrm{E}-04$ & $7.566 \mathrm{E}-04$ & 0.000 & $7.566 \mathrm{E}-04$ & 0.000 & $9.060 \mathrm{E}-04$ & 19.746 \\
\hline Efficiency & 0.2881 & 0.2880 & -0.035 & 0.2888 & 0.243 & 0.2885 & 0.139 \\
\hline
\end{tabular}

Table 6

Sensitivity analysis for control Structure No. 1.

\begin{tabular}{|c|c|c|c|c|c|c|c|}
\hline & Base case & $P(-1 \%)$ & Variation (\%) & $P(-5 \%)$ & Variation (\%) & $P(-10 \%)$ & Variation (\%) \\
\hline \multicolumn{8}{|l|}{ Disturbance in current load } \\
\hline XE (ethanol molar fraction in \%) & 1 & 1 & 0.000 & 1 & 0.000 & 1 & 0.000 \\
\hline $\mathrm{FA}\left(\mathrm{kmol} \mathrm{h}^{-1}\right)$ & $2.936 \mathrm{E}-02$ & $2.906 \mathrm{E}-02$ & -1.022 & $2.788 \mathrm{E}-02$ & -5.041 & $2.642 \mathrm{E}-02$ & -10.014 \\
\hline $\mathrm{FE}\left(\mathrm{kmol} \mathrm{h}^{-1}\right)$ & $7.340 \mathrm{E}-03$ & $7.265 \mathrm{E}-03$ & -1.022 & $6.970 \mathrm{E}-03$ & -5.041 & $6.605 \mathrm{E}-03$ & -10.014 \\
\hline $\mathrm{FEC}\left(\mathrm{kmol} \mathrm{h}^{-1}\right)$ & $7.581 \mathrm{E}-04$ & $7.511 \mathrm{E}-04$ & -0.923 & $7.222 \mathrm{E}-04$ & -4.736 & $6.875 \mathrm{E}-04$ & -9.313 \\
\hline Efficiency & 0.2881 & $2.880 \mathrm{E}-01$ & -0.035 & $2.880 \mathrm{E}-01$ & -0.035 & $2.879 \mathrm{E}-01$ & -0.069 \\
\hline
\end{tabular}

Table 7

Sensitivity analysis for control Structure No. 2 .

\begin{tabular}{|c|c|c|c|c|c|c|c|}
\hline & Base case & $P(-1 \%)$ & Variation (\%) & $P(-5 \%)$ & Variation (\%) & $P(-10 \%)$ & Variation (\%) \\
\hline \multicolumn{8}{|l|}{ Disturbance in current load } \\
\hline XE (ethanol molar fraction in \%) & 1 & 1 & 0.000 & 1 & 0.000 & 1 & 0.000 \\
\hline $\mathrm{FA}\left(\mathrm{kmol} \mathrm{h}^{-1}\right)$ & $2.936 \mathrm{E}-02$ & $2.905 \mathrm{E}-02$ & -1.056 & $2.778 \mathrm{E}-02$ & -5.381 & $2.618 \mathrm{E}-02$ & -10.831 \\
\hline $\mathrm{FE}\left(\mathrm{kmol} \mathrm{h}^{-1}\right)$ & $7.340 \mathrm{E}-03$ & $7.263 \mathrm{E}-03$ & -1.049 & $6.945 \mathrm{E}-03$ & -5.381 & $6.545 \mathrm{E}-03$ & -10.831 \\
\hline $\operatorname{FEC}\left(\mathrm{kmol} \mathrm{h}^{-1}\right)$ & $7.581 \mathrm{E}-04$ & $7.566 \mathrm{E}-04$ & 0.000 & $7.566 \mathrm{E}-04$ & 0.000 & $7.566 \mathrm{E}-04$ & 0.000 \\
\hline Efficiency & 0.2881 & $2.879 \mathrm{E}-01$ & -0.069 & $2.877 \mathrm{E}-01$ & -0.139 & $2.875 \mathrm{E}-01$ & -0.208 \\
\hline
\end{tabular}

subtracting the electrical energy needed to operate FCS auxiliaries such as pumps and compressors divided by the heating value of the ethanol consumed in the fuel processor for reforming and burning,

$\eta_{\mathrm{FPS}}^{\mathrm{HHV}}=\frac{P_{\text {system }}}{\mathrm{HHV}_{\mathrm{Et} .} \times(\mathrm{FE}+\mathrm{FEC})}$

The HV factor can be the higher heating value (HHV) or the lower heating value (LHV) of the ethanol. HHV represents the actual amount of chemical energy in the fuel (relative to standard conditions), while LHV neglects heat below $150^{\circ} \mathrm{C}$. In Tables $2-5$ the HHV are included.

From the simulation results can be concluded that Structure No. 1 does not present significant variation on the efficiency however the porcentual variations on the manipulated variables are more important than those produced using Structure No. 2. In this last one the efficiency is kept closed to the same value of the base case. The stronger effect is detected for the $F_{\mathrm{EC}}$ when a disturbance at molar fraction of about $10 \%$ occurs, the FEC reaches the $40 \%$ of variation. It indicates that Structure No. 1 is the most sensitive since actuators saturation are probable to occur during the operation plant and, as a consequence, a lost of controllability. For Structure No. 2 the variation is less than that produced in Structure No. 1 even though its magnitude indicates to be careful on the controller to be chosen for this specific case.

\section{Conclusions}

An efficient ethanol processor depends on the ability to keep the process at operating conditions of the reformer and their efficient energetic integration obtained from the conceptual design. The influence of some critical perturbations can produce that several variables move away from the desired point. Hence, accounting with a good steady-state model helps for screening several control structures by a disturbances sensitivity analysis. This methodology is useful for showing the capability of the model to evaluate alternative control strategies. Hence this preliminary exploration, accounting the main factors of the most critical elements of the plant, is useful for reducing the control dimensionality which can be further investigated if a control-oriented dynamic model can be accounted for the later test. As it is understood, this is the first work which proposes a plantwide control for this kind of process. In future works it is thought to include the dynamic behavior of the other auxiliary equipment and perform a deeper study on the final control structure and the controller synthesis.

\section{References}

[1] D. Ho, V. Lightner, Fuel Cell Seminar, Mira Digital Publishing, San Antonio, 2004

[2] S.P. Asprey, B.W. Wojciechowski, B.A. Peppley, Appl. Catal. A: Gen. 179 (1999) 51. 
[3] J.C. Amphlett, R.F. Mann, B.A. Peppley, Int. J. Hydrogen Energy 21 (8) (1996) 673.

[4] D.K. Liguras, K. Goundani, X.E. Verykios, J. Power Sources 130 (2004) 30.

[5] R. Evans, S. Czernik, K. Magrini-Bair, DOE Hydrogen Program, FY2004 Progress Report, 65.

[6] A. Qi, B. Peppley, K. Karan, Fuel Process. Technol. 88 (1) (2007) 3-22.

[7] W. Powers, P. Nicastri, Control Eng. Pract. (2000) 605-618.

[8] D. Boettner, G. Paganelli, Y. Guezennec, G. Rizzoni, M. Moran, ASME J. Energy Resour. Technol. 124 (2002) 20-27.

[9] W.E. Mufford, D.G. Strasky, United States Patents 5,991,670 (1999).

[10] J.T. Pukrushpan, A.G. Stefanopoulou, H. Peng, Control of Fuel Cell Power Systems: Principles, Modeling Analysis and Feedback Design, Springer, 2004

[11] P. Rodatz, A.G. Paganelli, L. Guzzella, Proceedings of the American Control Conference, Denver, CO, 2003, pp. 2043-2048.

[12] J. Pukrushpan, A. Stefanopoulou, S. Varigonda, J. Eborn, C. Haugstetter, Control Eng. Pract. 14 (3) (2006) 277-293.
[13] H. Gorgun, J. Electr. Electron. Eng. 5 (1) (2005) 1279-1286.

[14] J. Francesconi, M.C. Mussati, R.O. Mato, P. Aguirre, J. Power Sources 167 (2007) 151-161.

[15] M.L. Luyben, W.L. Luyben, Essentials of Process Control, McGraw-Hill Chemical Engineering Series, International Editions, 1997.

[16] W.L. Luyben, B.D. Tyreus, M.L. Luyben, Plantwide Process Control McGraw-Hill Chemical Engineering Series, International Editions, 1999.

[17] HYSYS ${ }^{\circledR}$ User Manual Aspen Technology, Inc., MA, USA, 2006.

[18] B. Linnhoff, D. Townsend, P. Boland, G.F. Hewitt, B.E.A. Thomas, A.R. Guy, R.H Marsland, A User Guide on Process Integration for the Efficient Use of Energy, Institute of Chemical Engineers, Rugby, UK, 1985.

[19] J. Godat, F. Marechal, J. Power Sources 118 (2003) 411-423.

[20] D. Feroldi, M. Serra, J. Riera, J. Power Sources 169 (2007) 205-212.

[21] W.L. Luyben, Plantwide Dynamic Simulators in Chemical Processing and Control, CRC Press, 2002. 